\title{
INTEGRATED APPROACH TO LEARNING (ON THE EXAMPLE OF A PRIVATE INSTITUTION “SCHOOL OF THE FREE AND RESPONSIVE")
}

\author{
OLHA PYLYPIV
}

\begin{abstract}
The current stage of reforming the Ukrainian national school is characterized by a complication of the content of education, an increase in the amount of information and a reduction in the time allotted for its learning. Today, the development of education as a system must be realized through systemic knowledge, which is necessary for forming holistic and systemic thinking. This knowledge can be obtained through the integration of the humanities and fundamental disciplines and should be guided by the global level of science development. This approach contributes to the formation of holistic ideas about the world and a human as a whole. These ideas are outlined by the author in the article.

The search for ways to improve the education system at school has helped revive the notion of integration of learning, which is gradually being implemented in primary school practice. The purpose of the article is to analyze the main aspects of an integrated approach to teaching at elementary school and to reveal the pedagogical value of thematic days. At the moment, the main task of education in the 21st century is to improve, develop and shape attention, imagination, thinking and memory. However, in general, today's level of the development of education in Ukraine does not give an opportunity to fully fulfill the function of the key resource of the socioeconomic development of the country and increase the welfare of citizens. The prestige of education and science in society remains low nowadays. Today, in Ukraine different legislative and regulatory acts provide the implementation of cardinal changes aimed at "a comprehensive development of a person as a personality and the highest value of society, shaping his or her talents, mental and physical abilities, upbringing high moral qualities, forming the citizens capable of a conscious public choice, enrichment on this basis of intellectual, creative, cultural potential of the nation, raising the educational level of the people, providing the national economy with qualified specialists. Ukraine recognizes education as a priority area of socio-economic, spiritual and cultural development of society" [7, p. 65].
\end{abstract}

Keywords: integration, thematic learning, content of education, elementary school, educational process.

\section{INTRODUCTION}

Based on the main tasks of the Ukrainian legislation on education and taking into account the social component of life and the health status of children and youth, the Ministry of Education and Science of 
Ukraine, which implements state policy, makes decisions on the organization of innovative activity in the field of education as well as coordinates and supervises its implementation.

In 2016, the concept of a New Ukrainian school was launched and the primary school programs were updated. It enables younger students to acquire key competences in a more comfortable way without being overloaded with theoretical information and increase motivation for learning. According to this, there are 10 key competences of the New Ukrainian School:

1. Communication in the national (and native in case of difference) languages.

2. Basic competences in natural sciences and technologies.

3. Digital competence.

4. The ability to learn throughout life.

5. Communication in foreign languages.

6. Mathematical competence.

7. Initiative and enterprising.

8. Awareness and expression in the cultural sphere.

9. Environmental literacy and healthy living.

10. Social and civic competences [11, p. 13].

Integrated learning is optimal for the current stage of development of the national school because at present there is a complication of the content of education, an increase in the amount of necessary information and a reduction in the time allotted for its learning [1, p. 96]. Along with the principles of humanization and differentiation, the principle of integration in Ukraine is proclaimed as one of the basic principles of educational reform. The importance of finding rational ways to integrate different disciplines in the process of primary education is also increased due to the students' overload with academic subjects, the thematic peculiarities of educational disciplines and the need to form a holistic outlook in the interconnection of its elements.

The research of didactic peculiarities of the integration of the content of teaching was performed by outstanding teachers: L. Varzatska, L. Horhosh, L. Nikolenko O. Prosina [3, 5, 10, 13]. Leading didactic and methodologists 'attention to the problem of integration is explained by the fact that it is aimed at enhancing information content and emotional enrichment of students' perceptions, thoughts and feelings through the attraction of additional interesting material, which enables to learn the phenomenon and concepts from different perspectives as well as to achieve the integrity of students' knowledge.

At present, the formation of personal qualities of young children in the integrated education is insufficiently scientifically substantiated, and numerous problems related to the creation of optimal conditions for their harmonious development in the educational process are not solved.

In the elementary school, much attention is paid to knowledge integration because, according to M.Vashulenko, there are objective reasons and preconditions for this, in particular: the need to eliminate children's overload; to reduce the number of teaching hours during the week and to allocate the withdrawn hours for the subjects of the developmental-educational cycle; the integrated course in elementary classes can be conducted by the class teacher at no extra cost, since he or she has to teach these subjects to students in the traditional way (as opposed to the upper classes) [4, p. 24].

\section{ANALYSIS AND DiscUSSION}

At present, the principle of integration in Ukraine has been proclaimed on the basic principle of educational reform along with the principles of differentiation and humanization. In the world countries, a lot of educational technologies are being developed and implemented on the basis of an integrated approach.

In primary school, the problem of integrated learning and education is important for both theory and practice. Its demand is inspired by new social requests for school and is caused by the changes in manufacturing and science. An integrated approach in the learning process serves as an important participant in enhancing students' learning and cognitive activity. 
Primary school has a major task to create the right conditions for the holistic development of the child's personality and self-organization. This can be done by solving the following problems: forming a sense of psychological protection in each student; creating the appropriate conditions for meeting the basic needs of the child in development, improvement, activity of his or her personality, etc.; creating reliable and trusting relations "teacher-student", "student-student", "student-teacher"; giving each child the opportunity to realize himself or herself in the most important areas of life, with the greatest possible development of his or her abilities and capabilities.

It is almost impossible to achieve and realize the set goals and objectives within the framework of traditional educational process. It involves a specific distribution orientation of educational and upbringing processes, despite the individual and mental characteristics of children as well as compliance with the common organization of the learning process with complex tasks for everybody, mode moments, division of the educational process not into the content, but into the time segments. Integration, as a leading trend of updating the content of education, gives the chance to qualitatively change the content of education, to supplement various subjects with interconnected knowledge in the history of science and psycho-economic, socio-philosophical and historical knowledge. Integration is a powerful way of forming an outlook, which does not have a regulatory but a personal character. Compliance with the terms of its successful methodological implementation provides with high-quality education that is competitive, able to create successful conditions for each student to independently achieve his or her own life goals and creatively affirm in various social sectors.

Advanced modern primary education teachers (M.S. Vashulenko, V.R. Ilchenko, Y.M.Kalyagin, O.Y. Savchenko, V.K. Sidorenko) emphasize two aspects of the concept of "integration":

1) creation of a holistic view of the outside world in primary school students (integration is seen as a goal of learning);

2) obtaining a common ground for combining subject knowledge (integration is used as a learning tool).

Introduction of the first aspect of the problem will allow to give students knowledge that shows the connection of certain components of the outside world to a single system, to develop students' visions of the outside world as a whole, where all the elements are interconnected and ordered. The worldwide experience of primary education with predominant integrated courses such as "A human and the Environment", "Humanities Integrated Course", "Art of Speech", "Artistic Work", "Music and Movement", etc. [15, p. 5] prove this position to be correct.

According to the National Strategy for the Development of Education in Ukraine for the period until 2021, "building a national education system in modern conditions, taking into account the fundamental changes in all spheres of public life, the historical challenges of the 21st century requires a critical reflection on what has been achieved and focusing efforts and resources on solving the most urgent problems that impede development and enable the provision of a new quality of education adequate to the current historical era" $[9$, p. 4].

Implementation of cross-curricular integration of the content of learning is a topical question of today, since the educational model based on integration helps students create a holistic picture of the world, form cross-curricular and key (extra-curricular) competences, stimulate the development of their cognitive and creative skills and solve the problem of intellectual overload of primary school students. The number of subjects based on only one science is reduced by the introduction of integrated courses based on knowledge of several related fields of science. The idea of integration in education is a significant achievement of didactics, since subject to its successful methodological implementation; the goal of high-quality education is realized [2, p. 15].

Therefore, integration as a requirement for combining into the whole of the components of learning objects is a necessary didactic means by which the creation of a holistic view of the object under study and a cross-curricular competence is formed among the students.

Y.A. Komensky also emphasized the need "to always bring together what is related to each other". The great didactic explained the need for an integrated thematic approach to the organization of the educational process in the following way: "All knowledge grows from one rootp - the surrounding 
reality; all knowledge is connected, and therefore, must be studied in connections." And "... in cases when the program material of different educational subjects allows to integrate itself within one school day, so-called "thematic days" can be organized, when all lessons in the schedule are directed for the implementation of a single educational goal, which finds a logical continuation in the educational event $^{\prime \prime}[14$, p. 245].

Integration acts as a natural interconnection of the sciences, disciplines, sections and topics of different subjects based on the leading idea and principles. At the present stage, there are three forms of integration: full, partial and box. Complete - merging educational material into a single course. Partial - merging most of the educational material with the selection of specific sections. Box - building standalone boxes with standalone programs or sections of a general program. It is more appropriate to start the integration with a box form, calculated for a quarter, six months or a year [8, p. 30].

A. Danylyuk believes that integration is an innovative technique that can solve many problems of education. Integration in the field of education and upbringing can be carried out at any stage of the pedagogical process, being a universal way of its transformation.

There are both favorable and unfavorable factors for integration in primary education. They largely determine the tactics of integration. Positive factors include the child's intelligence. Negative factors include a limited number of subjects, the need to develop extremely important reading, writing and numeracy skills. They require subject training [6, p. 28].

The traditional experience of teaching reading and mathematics testifies to the broad integration possibilities that can be further enhanced. However, not every combination of different disciplines becomes integrated learning.

Integration of a school content may be complete or partial. Integrated courses have become a characteristic feature of elementary schools in the most foreign countries. For example, reading, writing and speaking are combined into the "Art of Speech"; theater, design, music and dances in "Artistic Directions", chess, thinking, mathematics in "Mathematical block". The experience of conducting integrated lessons shows that their methodology requires a very high level of teachers' professionalism and erudition.

The main ideas of integrated learning are focused on personality (the person is the main value of the educational process); priority of the main motivations in learning (impelling, internal, external and organizational); systematic learning; problematic learning; reflection.

The purposes of integrated learning are as follows: to form students' holistic worldview, activate their cognitive activity, improve the quality of mastering the perceived material, form a creative atmosphere in the team, identify students' abilities and their peculiarities, form skills of individual work with additional literature, supporting words and schemes, effectively implement the development of educational function of learning, etc.

The main task of cross-curricular communication is to duplicate the educational material, even if it has been studied for a long time. Students usually can revise the previously learned material on other subjects on their own or at the teacher's instruction; however, there should be not only revision but also knowledge deepening during integrated lessons. Forming a cross-curricular concept is the final step in establishing cross-curricular relationships. The new generalized cognition result, the summary of the cross-curricular links must be expressed verbally. That is why, cross-curricular integration should be implemented in teaching methods and consolidated in students' skills, not just applied in content.

Therefore, the primary school teacher should focus on the main components of the New Ukrainian School Concept:

1. The new content of education, based on the formation of competencies needed for successful self-realization in society.

2. The needs of the student in the educational process, child-centrism.

3. The continuous education process which forms values.

4. Pedagogy, which is based on partnership between pupil, teacher and parents [12, p. 136].

However, the integration of learning requires skills, creativity, inspiration, teacher's desire, careful preparation and personality based communication with students [16, p. 105]. 
Integrated lessons often contain a considerable amount of material. So it is better to distribute this material into several lessons. This enables students to gain comprehensive knowledge on the topic and not overwhelm children with the amount of the material in one lesson.

Obviously, meaningful and purposeful integrated lessons bring novelty and originality into the familiar structure of schooling and have some advantages:

- promote development to a greater extent than ordinary lessons of attention, memory, students' thinking (logical, artistic, creative), aesthetic perception, imagination;

- increase motivation, form cognitive interest, which leads to a higher level of students' inspiration and better manners;

- contribute to the formation of a coherent scientific picture of the world and seeing subjects and phenomena from different perspectives: theoretical, practical and applied;

- promote the development of oral and written speech, help to understand more deeply the lexical meaning of the word, its aesthetic essence;

- allow to systematize knowledge.

It is noticeable that conducting integrated lessons leads to increasing the teacher's professional skills, as it requires mastering the methodology of new technologies of the educational process, additional time for preparation and implementation of an active approach to learning.

A survey of the teachers of the School of the Free and Responsive showed that during such studies, the information on different subjects is successfully combined around a single topic, which promotes information enrichment of students' perceptions, thoughts and feelings by involving interesting material. The pedagogical staff of this educational institution successfully uses the idea of such education because it leads to the achievement of the goal of high-quality education, allows to learn comprehensively about some phenomenon, concepts and to achieve the integrity of knowledge. For example, when studying literary reading, students acquire knowledge in literature and art, form practical skills and develop creative abilities.

Having conducted a survey of the pedagogical staff of the School of Free and Responsive (18 teachers of 1-4 grades) who work after NUS-2, namely: according to the textbook on Mathematics (O.M. His, I.V. Filyak.), "I am exploring the world" (O.V. Voloshchenko, A.P. Kozak) and copyright textbook "Ukrainian language" (author - Ulyana Dobrika), it turned out that most of them face some difficulties in implementing cross-curricular relations in the process of applying an integrated approach in teaching younger students. They include:

- ignorance of algorithms for the implementation of knowledge integration (choice of integrating factor);

- establishing the type of integration and integration links;

- creation of an integrated object;

- lack of appropriate scientific and methodological recommendations and complexes;

- the complexity of involvement of the teachers of other disciplines in integrated classes;

- lack of time to develop integrated content of disciplines, etc.

While observing the students during the usual lessons, we noticed complaints of lack of attention and misconduct due to the constant static and uniformity of tasks. The problem is that during prolonged and difficult work, the body not to bring itself to fatigue, sort of disconnects consciousness from the object of activity and shifts the focus to another object. Words, exclamations, orders in this case will not help. It takes a little rest to get the desired result - mindfulness. You also need to periodically do exercises, encourage attention that is easily achieved by changing activities.

Children's developed attention ensures an integrated lesson. It is a powerful stimulator of the child's mental activity. Students begin to analyze, collate, compare, find connections between objects and phenomena. Keeping the general direction, the attention periodically increases and diminishes. Alternating tension and relaxation is a "must" for the attention stability.

After conducting an integrated lesson in mathematics and literary reading in "Vilnodumtsi" Experimental Class, we have noticed a significant increase in attention, imagination, activity and research. The topic of the lesson was "Characteristic features of a rectangle and a square. Construction 
of a rectangle and square with given lengths of sides. The first printed books, their appearance, size and shape". It had a threefold purpose:

- educational: to specify the concept of a rectangle and a square; familiarize with their characteristic features; teach to find the perimeter of these figures; continue developing computing skills; improve problem solving skills; enrich with knowledge on the history of the book.

- developmental: develop attention, logical thinking, mathematical language, ability to compare, analyze, draw conclusions, improve reading skills and develop the ability to briefly retell what has been read.

- upbringing (to cultivate accuracy in the construction of figures and calculation of their perimeter; neatness, diligence and interest in books).

- required equipment for the lesson: a textbook on mathematics and literary reading for the 3rd form, riddles, books of various forms, additional tasks.

During the organizational moment, the students were told where we are surrounded by squares and rectangles, that they are present on Ukrainian embroideries, on our desks, in our class, at home and surround us throughout our lives. Kazymyr Malevich "Black Square" gave an example of the artistic painting. The teacher elicited from the students where they meet a square and a rectangle in their everyday life. The attention was also paid to the appearance of books. The children told about the books, their shapes, year of publishing, number of pages, their cost, etc. Therefore, we learned what the students were aware of before teaching the topic. To find out the topic and aim of the lesson, the children solved three riddles (about a square, a rectangle, and a book). They were pictured on the board and having guessed them, students showed the guess cards. We started working on the topic with a fairy tale called "Relatives". It described the life of an important figure called Square. At the beginning there was only a description of this figure, and later the students named it. In the tale, the Square had to find his relative called Rectangle. While listening to the tale, the students had to name the common and the distinctive features of a square and a rectangle.

Then followed the work with a textbook on mathematics and literary reading. The students did tasks and solved problems on the subject of the first book, in particular the time when it was written. They also learned that the books were very expensive, because they were handwritten; therefore, only wealthy people could read them. Later, students worked on vocabulary (connecting words with their meaning); reading the text aloud; working with expressions the results of which had to be replaced by the letters that formed the sentence about the book; book tasks; discussion of the books in the class library, etc.

Observing the activities of the students at the lesson, it is clear that learning directly depends on their feelings, experience, and interest. The complex interplay of external and internal conditions gives the result of drawing up an associative series, developing critical thinking and analyzing the situation. Physical activities were held with the children, in which math and literary reading were combined. The students eagerly participated, and several students were given the opportunity to demonstrate the movements for the rest of the class.

After that, knowledge of the perimeter of the rectangle and the square was reinforced. Selective reading (description of the printing process) was done and the "Press Conference" game was played. There was a student who was an author, a student an author's representative, and the rest of the students were journalists. The task was as follows: the author's representative gives a floor to the journalists, the journalists, in turn, come to the microphone, say their name, ask questions and the author gives the answers. The main requirement was that the questions could only be asked about the content of the lesson (the text that was read, solved problems, books' discussion, etc.).

To reinforce the learned material, the cards with various geometric shapes were handed out. The teacher described a figure, and the students had to color it in the appropriate color. During the reflection, the game "Tangle" was used, in which the students had to tell what they learnt during the lesson while unwinding a tangle. The teacher also used questions and assignments from other subjects relevant to the study of its topic at the integrated lesson. The teacher asked the students the following questions: 
- Where was the first printed book written? Which continent is this country on?

- Who was the first printer?

- Where are the books stored? Where are the books in our classroom stored?

- In what language was it written?

- Who created the first large library in Ukraine? Where was it situated?

- What were the first printed letters like? How did they differ from the modern ones?

These are simples at the lessons that contribute to the deeper perception and comprehension of a particular concept or phenomenon. Guided by the main didactic goals, we sought the best combination of integrated learning tools, avoiding the unwanted accumulation of activities that only made children feel tired. Using a variety of riddles, tasks, cards of various forms, it was possible to keep the children's attention as long as possible. The students shared different information about the subject of the study with interest, actively answered the questions, worked in pairs and groups. As the topic of the lesson was related to the books, they brought them from their home libraries. Particular attention was paid to the fact that each book had a different shape, texture, volume, year of publishing. The children calculated the books' perimeters, counted the number of pages, searched for the oldest book, grouped them together according to common features, and looked for differences. During the physical activity, the students had to line up with their books in ascending or descending order, depending on the number of pages, calculated perimeter, as well as to divide into the groups according to the shapes (rectangles or squares).

In the control class "Dreamers", two separate lessons in Mathematics and Literary reading were held. The topics were the same, but they were not related at the lesson. The lesson lasted 40 minutes. Observations showed that children were often distracted by different sounds, and their fatigue was evident. Despite the presence of physical activities during the lesson, students often checked back teacher's questions, did the tasks for a long time. In general, the lessons were successful; the children learned the presented topics well.

An important task of a primary school teacher is to involve younger students in cognitive activities, create the necessary conditions for integrated learning. Using integrated approach to teaching contributed to expanding the social and cognitive experience of students in line with the teacher's specific educational tasks, development of critical thinking in the students, increasing motivational activity, intensive students' development in terms of selected topics, improvement of memory, attention, imagination, shaping interest to the events and phenomena of reality, as well as the expansion of a holistic system of ideas about the world.

The analysis of the previous programs for the four-year primary school and the study of teachers' work, show great opportunities for integration of teaching material in individual subjects. The thematic unity of the subjects allowed teachers to plan integrated topics for the lessons. Thematic integration has certain ways of accomplishing its tasks: integrated lessons; integrated courses; binary lessons; integrated thematic days; cross-curricular lessons and thematic training.

Therefore, the advantage of the thematic integration of learning is the creation of prerequisites for the formation of not a narrowly informed specialist, but a creative personality who has a holistic world outlook and is able to actively work in the social and professional sphere. Also, as a result of this approach to learning, students get a holistic picture of the world in terms of the content of the vertical theme. The point of contact of different subjects is important as it helps to shape the student's worldview, reveals his or her attitude to the world, nature, society and him or herself.

Cross-curricular links make it possible to deepen the study of the material at no additional cost, to realize mutual systematic coherence, to stimulate students to use the acquired knowledge in everyday practice.

The teachers of "School of the Free and Responsive" have found out that the use of the integrative forms of learning helps build understanding and improve the cooperation of teachers and students in the learning process, as well as makes it possible to use the potential for the content of educational material more widely, form the motivation of students' learning and develop their creative abilities. 
Integrated lessons provide students with an integrated system of ideas about the world, their relationship and interdependence; contribute to deepening and expanding students' knowledge. Integrated lessons increase cognitive interest, develop imagination, attention, thinking, speech and memory, encourage active cognition of the surrounding reality, understanding and finding cause and effect relationships, as well as developing logic, thinking and communicative abilities.

\section{CONCLUSIONS}

To sum up, the integrated lesson in the elementary school introduces novelty, originality, contributes to the formation of a holistic picture of the world, examining the subject from different perspectives; it allows to systematize knowledge, create favorable conditions for the realization of personally oriented education. Therefore, an integrated lesson at the elementary school deserves much attention. It enhances the effectiveness of learning because students find new logical connections in the educational material based on the knowledge acquired in other subjects. This, in turn, develops their interest in learning, activates thinking, makes their knowledge conscious and strong. Moreover, crosscurricular links make it possible to use the time for studying the material in a rational way and significantly reduce the students' workload.

The teachers concluded when creating appropriate pedagogical conditions, the use of integrated lessons develops, shapes and contributes to the stability of students' attention, cognitive activity, intellectual and creative initiative, interest in acquiring new knowledge, skills and abilities.

Therefore, integration in today's school is a time requirement that is relevant to all teachers who are interested in developing a comprehensively competent student who perceives the world holistically and is able to actively participate in social and professional spheres.

\section{REFERENCES}

[1] Bishova T. Integrated lessons. Shkilnyi Svit, Kyiv, 2011. (in Ukrainian)

[2] Bilyaev O. Integrated lessons of the mother tongue. Dyvoslovo, 5 (2010), 15-19. (in Ukrainian)

[3] Varzatska L.O. Ukrainian language. Organizing integrated lessons in elementary grades, 4. Bohdan Publishing House, Ternopil, 2017. (in Ukrainian)

[4] Vashulenko M. Integrated course program (literacy, mathematics, the outside world). Pochatkova Shkola, 8 (2001), 24-31. (in Ukrainian)

[5] Gorgosh L. What is integration? It's worth understanding. Uchytel Pochatkovoi Shkoly, 9 (2018), 32-35. (in Ukrainian)

[6] Danyliuk A.Ya. Educational subject as an integrated system. Pedagogika, 4 (1997), 24-28. (in Ukrainian)

[7] Law of Ukraine “On Education". Available at: https://zakon.rada.gov.ua/laws/show/1060-12 (in Ukrainian)

[8] Kolyagin Yu. M. Integration of school education. Pochatkova Shkola, 9 (1990), 28-31. (in Ukrainian)

[9] National doctrine of education development of Ukraine in the XXI century. Available at: https://zakon.rada.gov.ua/laws/show/347/2002 (in Ukrainian)

[10] Nikolenko L.T. The New Ukrainian School: An Integration Approach in Primary General Education. Metodyst, 2 (74) (2018), 72-74. (in Ukrainian)

[11] New Ukrainian School. Conceptual principles of secondary school reform. Available at: https://mon.gov.ua/storage/app/media/zagalna\%20serednya/nova-ukrainska-shkola-compressed.pdf

[12] Bibik N.M. New Ukrainian School: Teacher Advisor. Pleiades Publishing House, Kyiv, 2017. (in Ukrainian)

[13] Prosina O. Integration into the NUSH. An integrated approach in the educational process. Metodyst, 2 (2018), 68-71. (in Ukrainian)

[14] Savchenko O.Ya. Didactics of elementary school. Genesis, Kyiv, 1999. (in Ukrainian) 
[15] Siukayeva O. Implementation of integrated days and lessons. Formation of a competent personality. Pochatkova Osvita, 6 (2013), 4-8. (in Ukrainian)

[16] Chekina O. Yu. Integrated lessons in elementary school. Osnova, Kharkiv, 2011. (in Ukrainian)

Address: Olha Pylypiv, Postgraduate Student, Primary School Teacher "Shkola Vilnykh ta Nebaiduzhykh", 39, Kleparivska Str., Lviv, 79007, Ukraine.

E-mail: olgapylypiv@gmail.com

Received: 03.02.2020; revised: 06.03.2020.

Пилипів Ольга. Інтегрований підхід до навчання (на прикладі приватного навчального закладу I ступеня "Школи вільних та небайдужих"). Журнал Прикарпатського університету імені Василя Стефаника, 7 (1) (2020), 214-222.

Для сучасного етапу реформування української національної школи характерним є ускладнення змісту освіти, зростання обсягу інформації і зменшення часу, відведеного для іiі засвоєння. Сьогодні розвиток освіти як системи повинен реалізуватися через системні знання, що $€$ необхідними для формування цілісного, системного мислення. Ці знання можуть бути отримані на основі інтеграції гуманітарних і фундаментальних дисципдін, які повинні орієнтуватися на світовий рівень розвитку науки. Такий підхід сприяе формуванню цілісних уявлень про світ і людину в цілому. Ці ідеї викдадені автором у статті.

Акцентовано, що пошуки шляхів удосконалення системи освіти в школі сприяли відродженню інтегрованого навчання, що поступово знаходить втілення у практиці початкової школи. У статті проаналізовано основні аспекти інтегрованого підходу до навчання у початковій школі та розкрито педагогічну цінність тематичних днів. Обгрунтовано, що основним завданням освіти у XXI столітті є вдосконалення, розвиток та формування уваги, уяви, мислення та пам'яті. Проте загалом сьогоднішній рівень розвитку освіти в Україні не дає змоги сповна виконати функцію кдючового ресурсу соціально-економічного розвитку держави і зростання добробуту громадян. Зазначено, що престижність науки та освіти в суспільстві нині залишається низькою. Тому на сьогодні в Україні різними законодавчими та нормативними актами передбачено упровадження кардинальних змін, спрямованих на “всебічний розвиток людини як особистості та найвищої цінності суспільства, формування ії талантів, розумових і фізичних здібностей, виховання високих моральних якостей, формування громадян, здатних до свідомого суспільного вибору, збагачення на цій основі інтелектуального, творчого, культурного потенціалу народу, підвищення освітнього рівня народу, забезпечення народного господарства кваліфікованими фахівцями. Україна визнає освіту пріоритетною сферою соціально-економічного, духовного і культурного розвитку суспільства" [7, c. 65].

Кдючові слова: інтеграція, тематичне навчання, зміст освіти, початкова школа, освітній процес. 